\title{
Evaluation of abdominal aortic aneurysm rupture in emergency department: Case report
}

\section{Acil serviste abdominal aort anevrizması rüptürünün değerlendirilmesi:: Olgu sunumu}

\author{
Yusuf Kenan Tekin ${ }^{1}$
}

Emergency Department, Cumhuriyet University, Sivas, Turkey

Corresponding author: Yusuf Kenan Tekin, Cumhuriyet University Faculty of Medicine, Emergency Department, TR-58140, Sivas, Turkey

E-mail: yktekin@hotmail.com

Received/Accepted: May 28, 2017 / September 29, 2017

Conflict of interest: There is not a conflict of interest.

\section{SUMMARY}

Abdominal aortic aneurysm (AAA) is a common chronic degenerative disease of the abdominal aorta leading to progressive dilatation, thrombosis, rupture and distal embolization. It is defined as exceed $30 \mathrm{~mm}$ or $50 \%$ increase in the normal diameter of the vessel and it is an important cause of morbidity and mortality. We report an exceptional case of an isolated AAA rupture in a 56 years old male with a previously undiagnosed AAA. The AAA rupture appeared during abdominal examination in the emergency department. It could be incidentally but also we want to emphasise that phsical examination or manuplation of abdomen should be done carefully if there are suspicion of AAA.

Keywords: Abdominal aortic aneurysms, abdominal aortic aneurysms complications, abdominal pain

\section{ÖZET}

Abdominal aort anevrizması (AAA) progresif genişleme, trombozis, rüptür ve distal embolizasyona sebep olan abdominal aortanın yaygın kronik dejeneratif hastalığıdır. Damar çapının 30 mm’den fazla olması veya normal damar çapının \%50 artması olarak tanımlanır. Mortalite ve morbiditenin önemli bir sebebidir. Burada, daha önce AAA tanıs1 olmayan ve izole AAA rüptürü tespit edilen 56 yaşında erkek hasta sunduk. Hasta acil serviste değerlendirilirken rüptür gerçekleşti. Tesadüf eseri olabilir, yine de AAA şüphesi varsa karın muayenesinin ve manüplasyonunun dikkatle yapılması gerektiğini vurgulamak isteriz.

Anahtar sözcükler: Abdominal aort anevrizması, abdominal aort anevrizması komplikasyonları, abdominal ağnı

\section{INTRODUCTION}

Abdominal aortic aneurysm (AAA) is a common chronic degenerative disease of the abdominal aorta leading to progressive dilatation, thrombosis, rupture and distal embolization. It is defined as exceed $30 \mathrm{~mm}$ or $50 \%$ increase in the normal diameter of the vessel. AAA is an important cause of morbidity and mortality. It is usually affect elderly men especially over the age of 65 , and its prevalence is $1.0-8.9 \%$ in the general population ${ }^{1-4}$. The incidence and prevalence of AAA are increasing, due to elongation of life expectancy and use of imaging diagnostic technic. The disaster complication of AAA is rupture of the aneurysm, mortality rate is over $80 \%$ and half of rupture are die before reach the hospital ${ }^{5}$.

We report an exceptional case of an isolated AAA rupture in a 56 years old male with a previously undiagnosed AAA. The ruptur occurred when patient was evaluated in the emergency department.

\section{CASE REPORT}

A 56-year-old male patient admitted to emergency department complaint of abdominal pain beginning two hours ago. His abdominal pain was 
intermittently present for three month. He is nonsmoker and haven't remarkable medical history except hypertension for ten years. His hemodynamics was stable, blood pressure was $110 / 70 \mathrm{mmHg}$, heart rate was $75 \mathrm{per} / \mathrm{min}$ with regular rhythm and respiration rate was $20 / \mathrm{min}$. His electrocardiography was in sinus rhythm. On abdominal physical examination tenderness with guarding and a palpable pulsatile abdominal mass was observed in the middle of the abdomen. The physical examination was otherwise unremarkable. Bilateral lower extremity pulsation were palpable. Abdominal ultrasonography was performed and abdominal aort transverse and anteroposterior diameter was $92 \mathrm{~mm}$ and there was mural thrombus in the aneurismatic area. Contrast-enhanced computed tomography scanning revealed an infrarenal abdominal aortic aneurysm that transvers diameter was 94 milimeters and also there was mural thrombus in the aneurismatic area

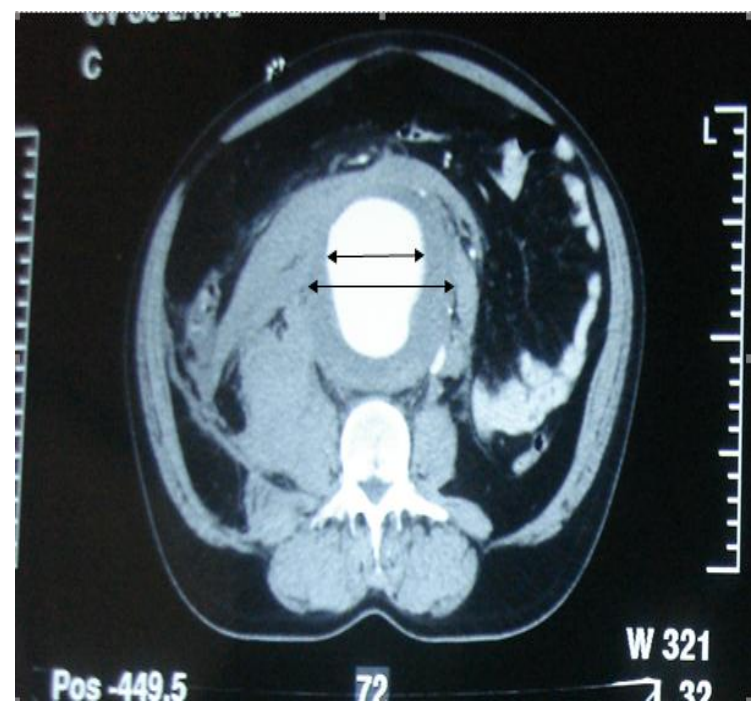

Figure 1: Transvers diameter of aneurysmatic inferior by aneurysmatic aortic segment

\section{DISCUSSION}

AAA is a common dejenerative disease of the abdominal aortic wall. Due to longer life expectancy, incidence is increasing with aging especially older man ${ }^{3,6}$. Atherosclerotic changes in the vessel wall are the most frequent cause of AAA 7. It is five times more common in men than in women. Risk factors are such as smoking, age, history of coronary artery disease, hypertension, low high-density lipoprotein (HDL) cholesterol concentration, high concentration of total serum cholesterol and chronic obstructive pulmonary disease ${ }^{5,6,8-10}$. AAA also has a higher prevalence in first-degree family members and ethnicity factors.
(Figure 1). Thoracal aorta was at normal vessel diameters. Vena cava inferior was compressed by anurysmatic aortic segment (Figure 2). There were no free fluid in both abdominal ultrasonography and computed tomography. The patient's abdominal pain was over again assessed by general surgery. When patient emergency department examination was continued, his hemodynamics finding was deteriorate suddenly. Blood pressure fall down $60 / 40 \mathrm{mmHg}$, heart rate increased 115 per/min and the superficial breathing. His consciousness was losed. Intubation was performed immediately. Admission hemoglobin was $11.3 \mathrm{~g} / \mathrm{dl}$ and reduced $7.4 \mathrm{~g} / \mathrm{dl}$ after patient hemodynamics was worsened. AAA rupture was tought and cardiovascular surgery performed emergency laparotomy. AAA rupture was detected in laparotomy. He has done discharged after surgery.

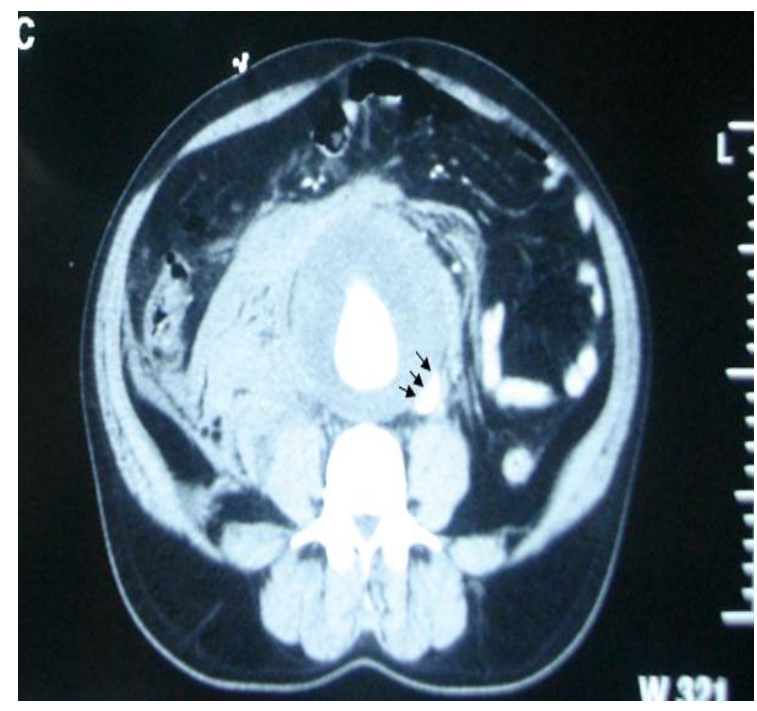

Figure 2: Compression of vena cava vessel

It is also more common in white people than in black people ${ }^{3,10}$.

The likelihood risk factors of AAA rupture are including aneurysm size, expansion rate, sex, continued smoking, uncontrolled hypertension and increased wall stress. Estimated annual rupture risk is $0 \%$ when vessel diameter is less than 40 milimeter and increase to $50 \%$ when vessel diameter is 80 milimeter or greater than this. It is thought that high risk for rupture when AAA expands 5 milimeter or more over than this during six months of follow-up ${ }^{3,11}$.

The treatment of ruptured AAA is emergent surgery or endovascular repair. The mortality rate is variable and dependent on the hemodynamic 
condition of the patient during the intervention. Operative mortality is approxymately $30-70 \%$ in ruptured $\mathrm{AAA}^{2,12}$.

In conclusion, we present a rare case of AAA rupture which was previously undiagnosed. The ruptur of AAA could be incidentally when patient was evaluated in the emergency department. But also physical examination and manuplation for ultrasonography could be a reason of rupture in the emergency department. So that, if there are a suspicion of AAA, physical examination or manuplation of abdomen should be done carefully due to risk of AAA rupture.

\section{REFERENCES}

1. Hellenthal FA, Pulinx B, Welten RJ, Teijink JA, van Dieijen-Visser MP, Wodzig WK, Schurink GW. Circulating Biomarkers and Abdominal Aortic Aneurysm Size. J Surg Res 2012; 176: 672-8.

2. Fedakar A, Findık O, Kalender M, Balkanay M. Unusual emergent presentations of abdominal aortic aneurysm: can simple blood tests predict the state of emergency? Ulus Travma Acil Cerrahi Derg. 2011; 17: 525-32.

3. Aggarwal S, Qamar A, Sharma V, Sharma A. Abdominal aortic aneurysm: A comprehensive review. Exp Clin Cardiol 2011; 16: 11-5.

4. Sakalihasan N, Limet R, Defawe OD. Abdominal aortic aneurysm. Lancet 2005; 365: 1577-89.

5. Balm R. Endovascular repair of ruptured abdominal aortic aneurysm. Br J Surg 2008; 95: 133-4.

6. Patel SN, Kettner NW. Abdominal aortic aneurysm presenting as back pain to a chiropractic clinic: a case report. J Manipulative Physiol Ther 2006; 29: 409.e1-7

7. Johnston KW, Rutherford RB, Tilson MD, Shah DM, Hollier L, Stanley JC. Suggested standards for reporting on arterial aneurysms. Subcommittee on Reporting Standards for Arterial Aneurysms, Ad Hoc Committee on Reporting Standards, Society for Vascular Surgery and North American Chapter, International Society for Cardiovascular Surgery. J Vasc Surg 1991; 13: 452-8.

8. Koen M van de Luijtgaarden, Ellen V Rouwet, Sanne E Hoeks, Robert J Stolker, Hence JM Verhagen and Danielle Majoor-Krakauer. Risk of abdominal aortic aneurysm (AAA) among male and female relatives of AAA patients. Vascular Medicine 2017; 22: 112-8.

9. Cornuz J, Sidoti Pinto C, Tevaearai H, Egger M. Risk factors for asymptomatic abdominal aortic aneurysm: Systematic review and meta-analysis of population-based screening studies. Eur $\mathbf{J}$ Public Health 2004; 14: 343-9.

10.Linné A, Forsberg J, Lindström D, Ideskog E, Hultgren R. Age at detection of abdominal aortic aneurysms in siblings of patients with abdominal aortic aneurysms. J Vasc Surg 2016; 63: 883-7.

11.Brewster DC, Cronenwett JL, Hallett JW Jr, Johnston KW, Krupski WC, Matsumura JS; Joint Council of the American Association for Vascular Surgery and Society for Vascular Surgery. Guidelines for the treatment of abdominal aortic aneurysms. Report of a subcommittee of the Joint Council of the American Association for Vascular Surgery and Society for Vascular Surgery. J Vasc Surg 2003; 37: 1106-17.

12.Mani K, Lees T, Beiles B, Jensen LP, Venermo M, Simo G, Palombo D, Halbakken E, Troëng T, Wigger P, Björck M. Treatment of abdominal aortic aneurysm in nine countries 2005-2009: a vascunet report. Eur J Vasc Endovasc Surg 2011; 42: 598-607. 